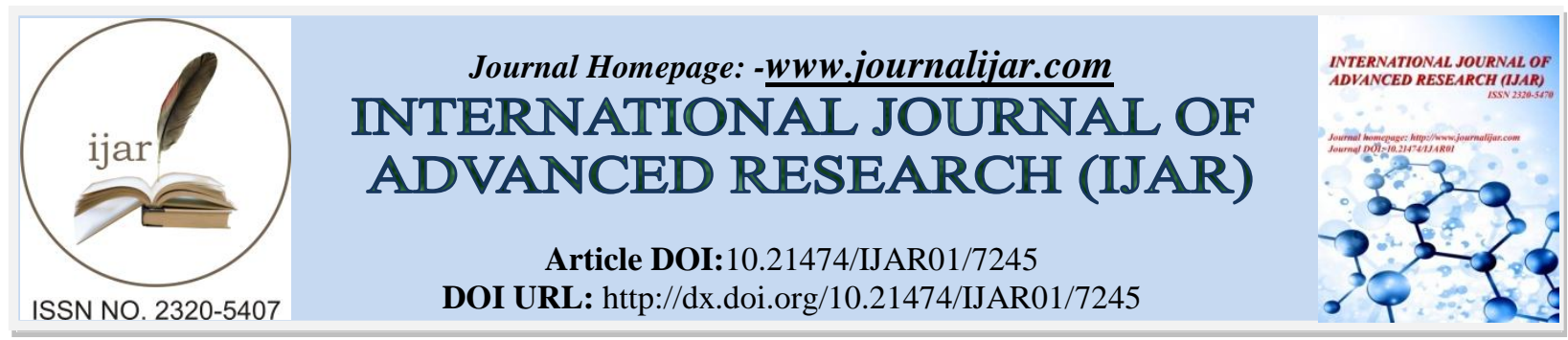

RESEARCH ARTICLE

\title{
EFFECTS OF HEARTFULNESS SELF DEVELOPMENT PROGRAM ON PSYCHOLOGICAL FLOURISHING OF STUDENT NURSES.
}

\author{
Raja Amarnath ${ }^{1}$, Latha Venkatesan ${ }^{2}$, Sugirtha Jenitha ${ }^{3}$, Shilpakala Vasudevan ${ }^{4}$, Banumathi $\mathrm{K}^{5}$ and \\ Krishnarao ${ }^{6}$. \\ 1. Professor- Department of Pulmonology and Critical care; Sree Balaji Medical College \& Hospital, Senior \\ Consultant- Apollo hospitals, Chennai, India. \\ 2. Principal and Professor in Maternal Health Nursing, Apollo college of nursing, Chennai, India. \\ 3. Clinical Researcher- Sree Balaji Medical College \& Hospital. \\ 4. Statistical Programmer and Heartfulness Trainer, Chennai, India. \\ 5. Asst. Professor in Community Health Nursing- Apollo College of nursing, Chennai, India. \\ 6. Senior IT Professional and Heartfulness Trainer, HP Enterprise, Chennai, India.
}

\section{Manuscript Info}

\section{Manuscript History}

Received: 10 April 2018

Final Accepted: 12 May 2018

Published: June 2018

\section{Keywords:-}

Nursing students, Psychological

flourishing, Heartfulness selfdevelopment program.

\section{Abstract}

Objective: To evaluate the effects of Heartfulness self-development program in improving psychological flourishing of nursing students.

Methodology: The study was designed as a prospective interventional study to examine the effects on positive psychological flourishing parameters such as empathy, optimism, self-confidence, positive outlook towards future, and social responsibilities. Participants of this study are students of a four-year undergraduate program in a nursing college in Chennai, Tamilnadu, India. Psychological flourishing scores [Ed Diener and Robert Biswas-Diener, 2009] were evaluated before and after a 24-week Heartfulness self-development program.

Results: Data from 174 students was collected and analyzed using SPSS version 21.There was a significant overall increase in the psychological flourishing of nursing students after the intervention [P < 0.000*]. This improvement persisted even in the subgroup analysis based on academic year and family background.

Conclusion: Significant improvements in psychological flourishing of nursing students were observed with the Heartfulness self-development program. Stress is a salient facet of nursing professionals, due to the excessive work load and long working hours they spend in tending to and taking care of patients. Nursing students experience substantial stress when they undergo training as nurses, and additionally endure anxiety from their academic pressures, financial concerns, family problems, and uncertainties of their future. In this study the intervention has substantially increased the self-confidence of the students, facilitating them to look within and explore their inner potential to successfully fulfil their goals and expectations. 


\section{Introduction:-}

Flourishing is a core concept in psychology that denotes the positive mental health and overall well-being of a person. It is considered as a state where individuals experience positive emotions, and positive psychological and social functioning most of the time, thus resulting in a person leading a life that is pleasant and meaningful. This is in contrast with the concept of languishing, where individuals feel hollow and have a sense of emptiness in their lives. Flourishing consists of four main components: goodness, generativity, growth, and resilience. A person needs to exhibit these traits, as well as cultivate strengths and virtues that are generically accepted across all cultures. Flourishing people display positive characteristics, like living their lives with a sense of purpose, having a locus of control, and choosing their own destiny instead of merely resigning to fate. They also tend to be happy and satisfied, but always look at avenues for growth and change in the right direction. Overall, they have very high levels of emotional, psychological and social well-being. While flourishing people are usually contented and happy, it is not required for them to feel good all the time, as it is quite natural for them to experience negative emotions like pain and anguish. However, well-being is affected when such emotions are intense and extended for a long period of time, thus inhibiting their daily functions in life (Diener ED et.al, 1985).One another aspect to psychological wellbeing is that it is different from ill-being, and an absence of ill-being does not imply that a person is psychologically well. (Fredrickson BL, 2005)There are a number of factors that lead to psychological flourishing. Research indicates that well-being results primarily from personality traits like low neuroticism, high extraversion and high conscientiousness (Ryff CD et.al, 2006). Findings from studies indicate that outcomes differ when taking personality traits into account compared to other factors (Keyes CL et.al, 2002). This is supported by the theory of chronic happiness which states that every individual genetically has a fixed set point for happiness that affects their longterm happiness and is the cause for the differences that occur in personality traits among people (Lyubomirsky $\mathrm{S}$ et.al, 2005). While it is true that there is a hereditary set point for psychological well-being, it does not mean that it cannot be increased and sustained over a period of time. One such method is to indulge in happiness related activities that one engages in intentionally, through one's effort (Sheldon KM, 2006).However, the passion with which they pursue the activity could potentially make a difference. If the passion is harmonious, it could positively influence well-being and protect against psychological ill-being, as the person is able to freely perform the activity and there is an autonomous internalization of the activity. On the other hand, if the passion is obsessive, it may result in anxiety and depression, since there is a rigid approach and an uncontrollable urge in the person to partake in the activity (Vallerand RJ, 2012).

Socio-demographic factors too affect flourishing to a certain extent. Having a high education, good employment, high income, and living with a partner is associated with good psychological well-being and social well-being. The effect of socio-demographics on well-being outcomes was found to be the least among other factors. Apart from personality traits and socio-demographics, other factors like social support and social participation are also correlated to flourishing and for creating long-standing happiness, resilience and vitality in an individual (Kahneman D, 2006).

The profession of nursing is central to delivering proper health care, and nurses play an important role in providing them to people across all countries. With the health care system undergoing significant changes and advancements in medical technologies, it is necessary to research the well-being of nurses. While many studies have been conducted over the years, to study the negative experiences and outcomes of working as nurses in the organizations, recent studies have started to focus on positive psychology and positive organizational behaviour (Brotheridge CM, 2002). Positive organizational scholarship (POS) is one aspect of psychology that advocates developing the right work conditions by advancing resilience, creating meaningfulness in life, engaging in positive relationships and promoting excellence within an organization. There are a lot of challenges associated with the job of nursing and nurses are considered as high-risk group for work stress (Fox ML et.al, 1993). The same applies to nursing students who experience stress and anxiety during their years of education and training. Some of the factors contributing to such stress are academic challenges, financial concerns, family problems, pressure to succeed and an uncertainty of the future. During their training period as nurses, they might have to work long hours in taking care and tending to patients, and partaking in the suffering, grief and death of people (Black B, 2016). Excessive work load carried out over a prolonged duration could affect the well-being of students. Learning to cope with stress is one of the best ways to deal with stress in everyday life. Coping can either be emotion focused, by decreasing emotional distress; or as problem focused, by making direct changes to the environment. Striving to be organized, planning well in advance, and maintaining priorities will significantly help in decreasing anxiety. Students that experience high levels 
of stress tend to be depressed and face impediments with their cognitive skills such as attention, memory and problem-solving skills. This results in students having a difficult time passing through school and not properly performing their clinical duties as a nurse, thereby affecting patient care (McHugh MD et.al, 2011).

Meditation is a tool that has proven to be helpful in dealing with the mental and emotional stress levels of people. Studies have shown multiple benefits of meditation on the physical health of a person such as blood pressure, heart rate and respiration (Amarnath RG et.al, 2017). On an emotional level too, meditation helps as a de-stressor by producing a relaxation effect on a person, and psychologically mitigating any anxieties. With meditation, one can gain a sense of balance which helps in developing capacities to accept and meet life's challenges. This study introduces Heartfulness relaxation and meditation to students of nursing to analyse its effects on psychological flourishing and its impact on positive factors like emotional stability, optimism, competency and vitality.

\section{Materials and Methods:-}

\section{Participants:-}

This study was conducted for students of a Nursing College, Chennai, India who were willing to participate in a selfdevelopment program involving Heartfulness Meditation. The purpose of the study was to perform pre-and postassessments of psychological flourishing conditions with the students. The population comprised of a total of 174 students of $1^{\text {st }}$ year, $2^{\text {nd }}$ year and $4^{\text {th }}$ year of education from the college. The $3^{\text {rd }}$ year students were however unable to participate in the study due to conflicts with their examination schedules.

\section{Tools:-}

Before the introduction of Heartfulness meditation, questionnaires were distributed to the nursing students to record their responses on 8 topics like competence, capability, happiness and wellbeing of others. Following that, meditation sessions were conducted once a week, for duration of 6 months (24 weeks). In each session, additionally, a series of topics, involving life skills, were discussed with students as part of the self-development program. Finally, after the conclusion of the 6 months sessions, the questionnaires were once again distributed to the students to gather their responses. Participants were not given prior information about the questionnaires to be filled in, both the times.

Table-I:-24-week self-development program

\begin{tabular}{|c|c|c|}
\hline Week & Topics & Objectives \\
\hline 1 & $\begin{array}{l}\text { Meditation - The technique to discover the } \\
\text { inner world }\end{array}$ & What is meditation? The technique \& its benefits. \\
\hline 2 & De cluttering the mind & $\begin{array}{l}\text { The technique of cleaning the mind and removing } \\
\text { unwanted thoughts. }\end{array}$ \\
\hline 3 & Time Management & $\begin{array}{l}\text { Deeper understanding of time. How to use time } \\
\text { effectively \& efficiently? }\end{array}$ \\
\hline 4 & Health - Balance of energies & $\begin{array}{l}\text { Different aspects of health. The secret of a healthy } \\
\text { life. }\end{array}$ \\
\hline 5 & Sleep Cycle \& Right nutrition & $\begin{array}{l}\text { Importance of the Sleep quality. Food Habits and } \\
\text { sleep. }\end{array}$ \\
\hline 6 & Success Through Excellence & $\begin{array}{l}\text { How can one be successful? Relationship between } \\
\text { success \& Excellence. }\end{array}$ \\
\hline 7 & Aptitude and Attitude & The difference. \\
\hline 8 & Dealing with Choices in life & How to make a right choice. \\
\hline 9 & A Stress-free Life & $\begin{array}{l}\text { Root cause of the Stress. How to lead a stress-free } \\
\text { life. }\end{array}$ \\
\hline 10 & From Outside to Inside & Centering your focus. \\
\hline 11 & Facing Challenges in life & $\begin{array}{l}\text { The right attitude and adaptability during difficult } \\
\text { times }\end{array}$ \\
\hline 12 & Introspection (Prayer) & The need for prayer, its efficacy. \\
\hline 13 & Designing Destiny & What is Destiny? Can we change it? \\
\hline 14 & Personality Development & What is personality? How to reform? \\
\hline 15 & Setting the Goal & How to set the goal in life? \\
\hline 16 & Taking Initiatives & Alert \& Observe. Work shop. \\
\hline
\end{tabular}




\begin{tabular}{|l|l|l|}
\hline 17 & Team Management & $\begin{array}{l}\text { How to be an effective member in a team, Team } \\
\text { dynamics? }\end{array}$ \\
\hline 18 & Dealing with failures & What is failure? How to handle failure? \\
\hline 19 & Ambition versus Aspiration & The difference and its applicability in life. \\
\hline 20 & The power of thought & $\begin{array}{l}\text { How your Positive thoughts can help one \& others } \\
\text { Relationship? }\end{array}$ \\
\hline 21 & Relationship & Managing the relationships in life. \\
\hline 22 & A Balanced life & How to find Balance in work \& personal life. \\
\hline 23 & Happiness - The way of life & How to be happy always? What makes us happy? \\
\hline 24 & My contribution to the society & $\begin{array}{l}\text { What can I do to my society? My role and } \\
\text { responsibility. }\end{array}$ \\
\hline
\end{tabular}

\section{Data Collection:-}

A standard questionnaire comprising of 8 questions pertaining to psychological flourishing (Diener E et.al, 2009) was used in the study.

Every week, the session started with a presentation on a life skill topic for 15 to 20 minutes, followed by a discussion for 5 to 10 minutes, and then guided relaxation for 5 minutes, followed by Heartfulness meditation with transmission for 20 minutes, and ending with self-observation and introspection by the students for the last 5 minutes.

A wide range of topics were discussed during the span of 24 weeks [Table-I].

Understanding what meditation is, how to meditate, the influence of our thoughts in our life, and how to declutter our mind with certain techniques were examined. Important concerns relating to modern times, like proper utilization of time, maintaining a healthy lifestyle and the importance of sleep and food habits were also discussed. Furthermore, personality development, team management, dealing with success and failure and facing challenges were also presented to the students. In addition to these, the effects of oneself on the society, our relationships and leading a balanced work and personal life were also reviewed.

\section{Data Analysis:-}

From the data that was collected from 174 nursing students, demographic frequencies were calculated, with the year of studies and family type as categories. Apart from this, paired t-test analysis was performed to analyse the relationship among the variables and subscales like optimism, competence, capability, happiness and well-being of others.

Data was conferred using inferential and description statistics in the pattern of counts, percentages and frequencies. Paired $t$ test was used to compare the mean between baseline and post Heartfulness meditation sessions, of nursing students.

\section{Results:-}

Mean, frequencies and percentages were computed for the demographic profiles as shown in Table-II. t-test was carried out on subscales in the questionnaire, pertaining to leading a purposeful life, having social relationships, being interested in daily activities, happiness and well-being of others, having competence and capability, being a good person, being optimistic and leading a good life. Comparison was done by studying mean values of pre- and post-meditation psychological flourishing scores of the participants. There is a mean increase in all considered subscales, post the meditation sessions [Table-V].

Table-II:-Demographic characteristics of the study population

\begin{tabular}{|c|c|c|c|}
\hline \multicolumn{2}{|c|}{ Variable } & Frequency & Percentage \\
\hline \multirow{2}{*}{ Year wise } & I YEAR & 77 & 44.3 \\
\cline { 2 - 4 } & II YEAR & 45 & 25.9 \\
\cline { 2 - 4 } & IV YEAR & 52 & 29.9 \\
\hline Type of family & JOINT & 52 & 29.9 \\
\hline
\end{tabular}




\begin{tabular}{l|l|l} 
NUCLEAR & 122 & 70.1
\end{tabular}

Out of total 174 participants, $77(44.3 \%)$ are $1^{\text {st }}$ year students, $45(25.9 \%)$ are $2^{\text {nd }}$ year students, and $52(29.9 \%)$ are $4^{\text {th }}$ year students. 52 students $(29.9 \%)$ of the total population are living as a joint family, while $122(70.1 \%)$ are living in a nuclear family system.

Complete demographic profile of participants is represented in Table-II.

Figure-1:-Pre \& Post self development program mean scores of psychological flourishing scales of students -year wise

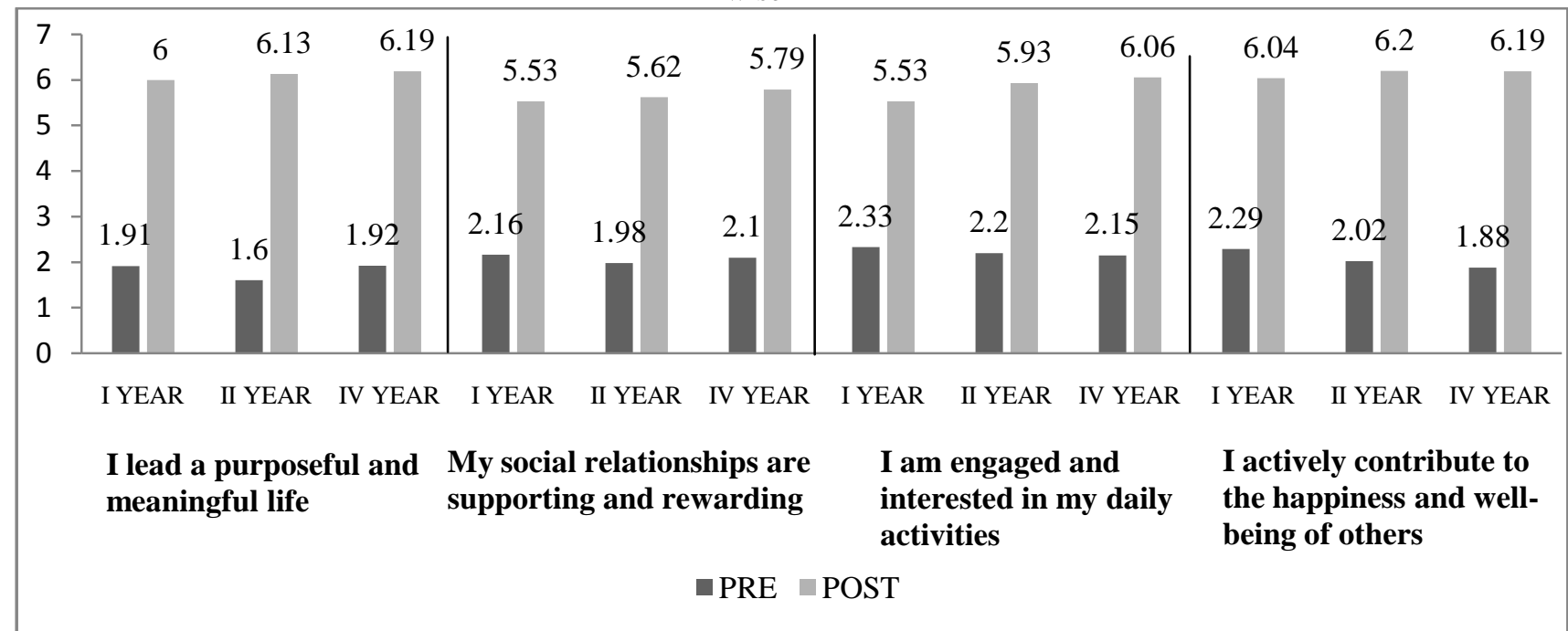

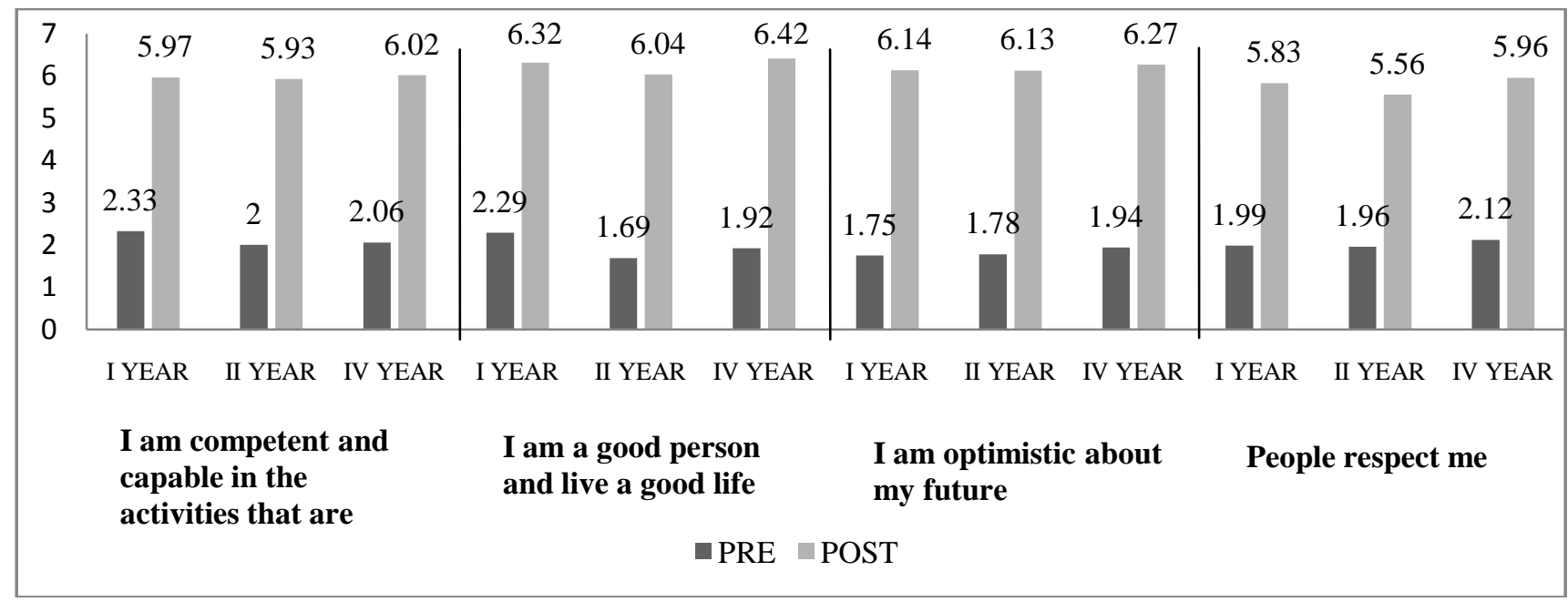

For each subscale, the mean values were derived for the students, year-wise, for pre and post meditation sessions. For the introspection on 'leading a purposeful life', $4^{\text {th }}$ year students had the highest mean in both pre and post meditation results [pre-mean $=1.92 \&$ post-mean $=6.19]$. For the subscale on 'social relationships and being engaged in activities', $1^{\text {st }}$ year students had the greatest mean [m=2.16], prior to meditation. However, for the same subscale, $4^{\text {th }}$ year students had higher mean values, post meditation $[\mathrm{m}=5.79]$. On the subscale regarding 'being an active contributor for happiness and well-being of others', $1^{\text {st }}$ year students had the highest mean values prior to meditation $[\mathrm{m}=2.29]$, whereas $2^{\text {nd }}$ year students had the highest mean values post meditation $[\mathrm{m}=6.20]$. Regarding the subscale on 'Being a competent, capable and a good person leading a good life', $1^{\text {st }}$ year's had the greatest scores before the meditation sessions $\left[\mathrm{m}=2.33\right.$ ], while $4^{\text {th }}$ year students had the highest mean values after the intervention $[\mathrm{m}=6.02]$. With respect to the subscale on 'Being optimistic of the future and having good respect from people', $4^{\text {th }}$ 
year students had the highest mean values in both pre and post meditation analysis [m=1.94 and $\mathrm{m}=6.27$, respectively]. Overall, $1^{\text {st }}$ year students had the highest mean scores for majority of the subscales prior to the beginning of the sessions, while $4^{\text {th }}$ year students had the highest mean values for most of the subscales post the meditation sessions as seen in Figure-1.

Table-III:-Comparison of pre \& post self development program psychological flourishing scores of students- year wise

\begin{tabular}{|c|c|c|c|c|c|c|c|c|c|}
\hline \multirow[t]{3}{*}{ Questionnaire } & \multirow[t]{3}{*}{ Education } & \multicolumn{5}{|c|}{ Paired Differences } & \multirow[t]{3}{*}{$\mathbf{t}$} & \multirow[t]{3}{*}{ df } & \multirow{3}{*}{$\begin{array}{l}\text { Sig. }(2- \\
\text { tailed) }\end{array}$} \\
\hline & & \multirow[t]{2}{*}{ Mean } & \multirow[t]{2}{*}{$\begin{array}{l}\text { Std. } \\
\text { Deviation }\end{array}$} & \multirow[t]{2}{*}{$\begin{array}{l}\text { Std. } \\
\text { Error } \\
\text { Mean }\end{array}$} & \multicolumn{2}{|c|}{$\begin{array}{c}\text { 95\% Confidence } \\
\text { Interval of the } \\
\text { Difference }\end{array}$} & & & \\
\hline & & & & & Lower & Upper & & & \\
\hline \multirow{3}{*}{$\begin{array}{l}\text { I lead a purposeful and meaningful } \\
\text { life }\end{array}$} & $1^{\text {st }}$ YEAR & -4.091 & 1.695 & .193 & -4.476 & -3.706 & -21.178 & 76 & $.000 *$ \\
\hline & $2^{\text {nd }}$ YEAR & -4.533 & 1.561 & .233 & -5.002 & -4.064 & -19.483 & 44 & $.000 *$ \\
\hline & $4^{\text {th }}$ YEAR & -4.269 & 1.716 & .238 & -4.747 & -3.791 & -17.937 & 51 & $.000 *$ \\
\hline \multirow{3}{*}{$\begin{array}{l}\text { My social relationships are } \\
\text { supporting and rewarding }\end{array}$} & $1^{\text {st }}$ YEAR & -3.377 & 1.792 & .204 & -3.783 & -2.970 & -16.534 & 76 & $.000 *$ \\
\hline & $2^{\text {nd }}$ YEAR & -3.644 & 1.300 & .194 & -4.035 & -3.254 & -18.812 & 44 & $.000 *$ \\
\hline & $4^{\text {th }}$ YEAR & -3.692 & 1.799 & .249 & -4.193 & -3.191 & -14.799 & 51 & $.000 *$ \\
\hline \multirow{3}{*}{$\begin{array}{l}\text { I am engaged and interested in my } \\
\text { daily activities }\end{array}$} & $1^{\text {st }}$ YEAR & -3.184 & 1.809 & .208 & -3.598 & -2.771 & -15.346 & 75 & $.000 *$ \\
\hline & $2^{\text {nd }}$ YEAR & -3.733 & 1.468 & .219 & -4.174 & -3.292 & -17.062 & 44 & $.000 *$ \\
\hline & $4^{\text {th }}$ YEAR & -3.904 & 1.683 & .233 & -4.372 & -3.435 & -16.723 & 51 & $.000 *$ \\
\hline \multirow{3}{*}{$\begin{array}{l}\text { I actively contribute to the happiness } \\
\text { of well-being others. }\end{array}$} & $1^{\text {st }}$ YEAR & -3.753 & 1.822 & .208 & -4.167 & -3.340 & -18.076 & 76 & $.000 *$ \\
\hline & $2^{\text {nd }}$ YEAR & -4.178 & 1.482 & .221 & -4.623 & -3.733 & -18.916 & 44 & $.000 *$ \\
\hline & $4^{\text {th }}$ YEAR & -4.308 & 1.579 & .219 & -4.747 & -3.868 & -19.679 & 51 & $.000 *$ \\
\hline \multirow{3}{*}{$\begin{array}{l}\text { I am competent and capable in the } \\
\text { activities that are important to me }\end{array}$} & $\mathbf{1}^{\text {st }}$ YEAR & -3.645 & 1.895 & .217 & -4.078 & -3.212 & -16.765 & 75 & $.000 *$ \\
\hline & $2^{\text {nd }}$ YEAR & -3.933 & 1.711 & .255 & -4.447 & -3.419 & -15.422 & 44 & $.000 *$ \\
\hline & $4^{\text {th }}$ YEAR & -3.962 & 1.571 & .218 & -4.399 & -3.524 & -18.180 & 51 & $.000 *$ \\
\hline \multirow{3}{*}{$\begin{array}{l}\text { I am a good person and live a good } \\
\text { life }\end{array}$} & $1^{\text {st }}$ YEAR & -4.039 & 2.835 & .323 & -4.682 & -3.395 & -12.501 & 76 & $.000 *$ \\
\hline & $2^{\text {nd }}$ YEAR & -4.356 & 1.640 & .244 & -4.848 & -3.863 & -17.818 & 44 & $.000 *$ \\
\hline & $4^{\text {th }}$ YEAR & -4.500 & 1.603 & .222 & -4.946 & -4.054 & -20.247 & 51 & $.000 *$ \\
\hline \multirow[t]{3}{*}{ I am optimistic about my future } & $1^{\text {st }}$ YEAR & -4.390 & 1.514 & .173 & -4.733 & -4.046 & -25.434 & 76 & $.000 *$ \\
\hline & $2^{\text {nd }}$ YEAR & -4.356 & 1.654 & .247 & -4.852 & -3.859 & -17.669 & 44 & $.000 *$ \\
\hline & $4^{\text {th }}$ YEAR & -4.327 & 1.768 & .245 & -4.819 & -3.835 & -17.647 & 51 & $.000 *$ \\
\hline \multirow[t]{3}{*}{ People respect me } & $1^{\text {st }}$ YEAR & -3.844 & 1.631 & .186 & -4.214 & -3.474 & -20.684 & 76 & $.000 *$ \\
\hline & $2^{\text {nd }}$ YEAR & -3.600 & 1.924 & .287 & -4.178 & -3.022 & -12.555 & 44 & $.000 *$ \\
\hline & $4^{\text {th }}$ YEAR & -3.846 & 1.753 & .243 & -4.334 & -3.358 & -15.819 & 51 & $.000 *$ \\
\hline
\end{tabular}

The magnitude of response for each subscale of 'psychological flourishing scale' after a '24 week self-development program' involving Heartfulness Meditation was different among the nursing students, when analysed based on the year of their study. For the subscale on leading a purposeful and meaningful life, $2^{\text {nd }}$ years had the greatest positive response $[\mathrm{m}=-4.533, \mathrm{t}=-19.483, \mathrm{p}<0.000]$ compared to the other year students. On the subscale related to being optimistic about the future, $1^{\text {st }}$ year students showed the maximum positive response $[\mathrm{m}=-4.390, \mathrm{t}=-25.434, \mathrm{p}<$ 0.000]. For the rest of the subscales in the questionnaire, final year students displayed the greatest positive response compared to the rest as seen in Table-III. 
Figure-2:-Pre \& post self development program mean scores of psychological flourishing scales of students based on the type of Family
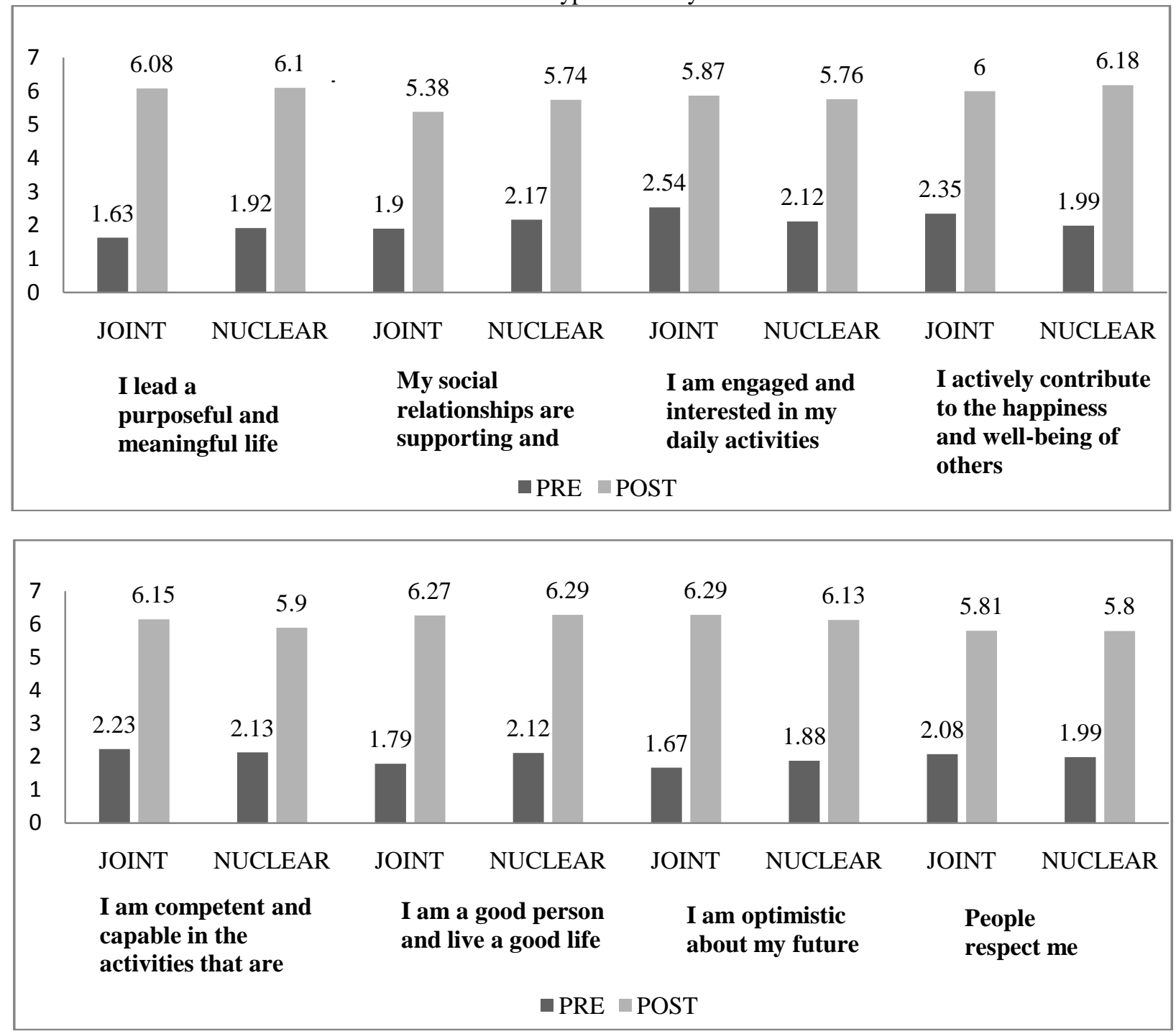

As seen in Figure-2, for each subscale, the mean values were derived for the students, family wise, for pre and post meditation sessions. For the subscales on 'Leading a purposeful life, having good social relationships, being a good person and living a good life and being optimistic', students belonging to nuclear family systems had higher mean values prior to meditation. For the remaining subscales, students of joint families showed greater mean values before meditation.

Post meditation, students belonging to nuclear families displayed higher mean for the subscales on 'Leading a purposeful life, having good social relationships, being an active contributor for happiness and wellbeing of others, being a good person and living a good life'. Students coming from joint family systems had higher mean for the rest of the subscales, post meditation. 
Table-IV:-Family wise comparison of pre \& post self development program psychological flourishing levels of students

\begin{tabular}{|c|c|c|c|c|c|c|c|c|c|}
\hline \multicolumn{10}{|c|}{ Paired Samples Test } \\
\hline \multirow[t]{3}{*}{ Questionnaire } & \multirow{3}{*}{$\begin{array}{l}\text { Type of } \\
\text { Family }\end{array}$} & \multicolumn{5}{|c|}{ Paired Differences } & \multirow[t]{3}{*}{$\mathbf{t}$} & \multirow[t]{3}{*}{ df } & \multirow{3}{*}{$\begin{array}{l}\text { Sig. } \\
(2- \\
\text { tailed) }\end{array}$} \\
\hline & & \multirow[t]{2}{*}{ Mean } & \multirow[t]{2}{*}{$\begin{array}{c}\text { Std. } \\
\text { Deviation }\end{array}$} & \multirow[t]{2}{*}{$\begin{array}{l}\text { Std. } \\
\text { Error } \\
\text { Mean }\end{array}$} & \multicolumn{2}{|c|}{$\begin{array}{c}95 \% \text { Confidence } \\
\text { Interval of the } \\
\text { Difference }\end{array}$} & & & \\
\hline & & & & & Lower & Upper & & & \\
\hline \multirow{2}{*}{$\begin{array}{c}\text { I lead a purposeful } \\
\text { and meaningful } \\
\text { life. }\end{array}$} & Joint & -4.442 & 1.564 & .217 & -4.878 & -4.007 & -20.476 & 51 & $.000 *$ \\
\hline & Nuclear & -4.180 & 1.711 & .155 & -4.487 & -3.874 & -26.994 & 121 & $.000 *$ \\
\hline \multirow{2}{*}{$\begin{array}{c}\text { My social } \\
\text { relationship are } \\
\text { supporting and } \\
\text { rewarding } \\
\end{array}$} & Joint & -3.481 & 1.777 & .246 & -3.975 & -2.986 & -14.128 & 51 & $.000 *$ \\
\hline & Nuclear & -3.566 & 1.641 & .149 & -3.860 & -3.271 & -23.994 & 121 & $.000 *$ \\
\hline \multirow{2}{*}{$\begin{array}{l}\text { I am engaged and } \\
\text { interested in my } \\
\text { daily activities }\end{array}$} & Joint & -3.327 & 1.746 & .242 & -3.813 & -2.841 & -13.742 & 51 & $.000 *$ \\
\hline & Nuclear & -3.636 & 1.693 & .154 & -3.941 & -3.332 & -23.625 & 120 & $.000 *$ \\
\hline \multirow{2}{*}{$\begin{array}{c}\text { I actively } \\
\text { contribute to the } \\
\text { happiness and } \\
\text { well-being others. }\end{array}$} & Joint & -3.654 & 2.085 & .289 & -4.234 & -3.073 & -12.635 & 51 & $.000 *$ \\
\hline & Nuclear & -4.189 & 1.451 & .131 & -4.449 & -3.928 & -31.890 & 121 & $.000 *$ \\
\hline \multirow{2}{*}{$\begin{array}{l}\text { I competent and } \\
\text { capable in the } \\
\text { activities that are } \\
\text { important to me }\end{array}$} & Joint & -3.923 & 1.845 & .256 & -4.437 & -3.409 & -15.329 & 51 & $.000 *$ \\
\hline & Nuclear & -3.769 & 1.716 & .156 & -4.078 & -3.460 & -24.152 & 120 & $.000 *$ \\
\hline \multirow{2}{*}{$\begin{array}{l}\text { I am a good person } \\
\text { and live a good life }\end{array}$} & Joint & -4.481 & 1.590 & .221 & -4.924 & -4.038 & -20.318 & 51 & $.000 *$ \\
\hline & Nuclear & -4.164 & 2.464 & .223 & -4.606 & -3.722 & -18.664 & 121 & $.000 *$ \\
\hline \multirow{2}{*}{$\begin{array}{l}\text { I am optimistic } \\
\text { about my future }\end{array}$} & Joint & -4.615 & 1.430 & .198 & -5.014 & -4.217 & -23.272 & 51 & $.000 *$ \\
\hline & Nuclear & -4.254 & 1.689 & .153 & -4.557 & -3.951 & -27.822 & 121 & $.000 *$ \\
\hline \multirow[t]{2}{*}{ People respect me } & Joint & -3.731 & 1.880 & .261 & -4.254 & -3.207 & -14.311 & 51 & $.000 *$ \\
\hline & Nuclear & -3.803 & 1.684 & .152 & -4.105 & -3.501 & -24.941 & 121 & $.000 *$ \\
\hline
\end{tabular}

Irrespective of the family background, there was a statistically significant increase, in the perception of all the subscales of psychological flourishing scale in the students $[\mathrm{p}<0.000]^{*}$ [Table-IV]

Table-V:-Overall comparison of pre \& post psychological flourishing level of students

\begin{tabular}{|c|c|c|c|c|c|c|c|c|}
\hline \multirow[t]{3}{*}{ Questionnaire } & \multicolumn{5}{|c|}{ Paired Differences } & \multirow[t]{3}{*}{$\mathbf{t}$} & \multirow[t]{3}{*}{ df } & \multirow{3}{*}{$\begin{array}{l}\text { Sig. (2- } \\
\text { tailed) }\end{array}$} \\
\hline & \multirow[t]{2}{*}{ Mean } & \multirow[t]{2}{*}{$\begin{array}{c}\text { Std. } \\
\text { Deviation }\end{array}$} & \multirow{2}{*}{$\begin{array}{c}\text { Std. } \\
\text { Error } \\
\text { Mean }\end{array}$} & \multicolumn{2}{|c|}{$\begin{array}{l}\text { 95\% Confidence } \\
\text { Interval of the }\end{array}$} & & & \\
\hline & & & & Lower & Upper & & & \\
\hline $\begin{array}{l}\text { I lead a purposeful and } \\
\text { meaningful life. }\end{array}$ & -4.259 & 1.668 & .126 & -4.508 & -4.009 & -33.677 & 173 & $.000 *$ \\
\hline $\begin{array}{l}\text { I am engaged and } \\
\text { interested in my daily }\end{array}$ & -3.543 & 1.710 & .130 & -3.800 & -3.287 & -27.255 & 172 & $.000 *$ \\
\hline $\begin{array}{l}\text { I actively contribute to } \\
\text { the happiness and well- }\end{array}$ & -4.029 & 1.678 & .127 & -4.280 & -3.778 & -31.679 & 173 & $.000 *$ \\
\hline
\end{tabular}




\begin{tabular}{|c|c|c|c|c|c|c|c|c|}
\hline $\begin{array}{c}\text { I am a good person and } \\
\text { live a good life }\end{array}$ & -4.259 & 2.239 & .170 & -4.594 & -3.924 & -25.088 & 173 & $.000 *$ \\
\hline $\begin{array}{c}\text { I am optimistic about my } \\
\text { future }\end{array}$ & -4.362 & 1.620 & .123 & -4.605 & -4.120 & -35.512 & 173 & $.000 *$ \\
\hline \begin{tabular}{c} 
People respect me \\
\hline
\end{tabular} & -3.782 & 1.740 & .132 & -4.042 & -3.521 & -28.670 & 173 & $.000 *$ \\
\hline
\end{tabular}

Overall, post-intervention highest magnitude of the response was observed pertaining to the optimism about the future $[\mathrm{m}=-4.362]$, followed by maximum response for the subscales 'leading a purposeful and meaningful life' [m=-4.259] and 'being a good person living a good life' [ $\mathrm{m}=-4.259]$.

The magnitude of positive response elicited for each subscale of 'psychological flourishing scale' after the ' 24 week self-development program involving Heartfulness Meditation', was statistically significant $\left[\mathrm{P}<0.000^{*}\right]$, rejecting the null hypothesis[Table-V].

\section{Discussion:-}

Nursing students in this study were initially found to have poor [average being 2 out of 7] psychological flourishing conditions. Some of the factors influencing this state could be: not realizing their purpose and meaning in life, having poor confidence on their competence, and stress related to studies and social relationships. On attending the Heartfulness self-development program, students were found to have significant improvements in many aspects like sociability, self-respect, caring for others, and trying to be a good person. It also helped them in getting trained on different topics, from time management to handling different challenges in life, which were also discussed in these sessions.

The current world we live in is filled with pressures and constant worries. With so many distractions around, we rarely take the time to relax or spend it in solitude. This can cause disorder in our system, affecting our physical and mental health. Often people are unable to identify the causes of these problems, and do not know how to resolve them to lead better lives.

Prior studies indicate that developing resilience to recover from stress and to adapt with the difficulties of life helps with improving psychological flourishing. Resilient people do so by developing positive emotions to effectively alleviate stress and adapt to it. Studies involving nursing students show that cultivating positive emotions like joy, interest, contentment, pride and love, greatly help in bouncing back from stress and replenishing one's condition. Engaging in activities that give enjoyment, and that obliterate the passage of time, helps in developing such emotions. Additionally, being grateful for all things in life, envisioning positive things in future and obtaining positive feedbacks with rewards and compliments has proved to be very beneficial in generating positive feelings and emotions (Fredrickson BL, 2001).

Meditation is proven to be very beneficial in dealing with stress and anxiety problems. Many studies conducted reveal countless benefits of meditation, such as, improved memory, increased creativity, better problem-solving skills, emotional stability and better overall well-being in people. With the happiness that is derived, a number of benefits can be experienced, ranging from better physical health and better relationships to high-level performance. Also, people experience an increased awareness; self-acceptance and emotional stability that help them deal with different situations with ease (Mishra S et.al, 2017).

This study reveals significant improvements in all the subscales of psychological flourishing scale for students, across all years of studies and family types.

When analysing the results year wise, it was observed that $1^{\text {st }}$ year students had the highest increase in scores pertaining to being optimistic about the future, than the other students, and seemed to have fewer apprehensions of the forthcoming prospects. This is perhaps due to the reason, that having just entered into their college life and into a professional course, they could be feeling more confident about the future job opportunities and not really experiencing the hard work they need to perform. $2^{\text {nd }}$ year students have busy schedules in their clinical postings and in also managing their academic activities in college, and $4^{\text {th }}$ year students might be filled with anxieties of their future. Among all the subscales, $4^{\text {th }}$ year students scored highest in "being good in social relationships", "being 
engaged and interested in activities", "actively contributing to other's happiness and wellbeing", "being competent and capable" and "being a good person, living a good life". This may well be attributed to their age and experience factor. Additionally, they felt they were more capable of performing tasks with ease, which indicates that they have better understanding and have gained more knowledge in their years of studying as compared to the first and second year students. The 2nd year students on the other hand, scored the highest in 'living a purposeful and meaningful life'. This is perhaps due to the reason that they feel more settled in and integrated into the system than the $1^{\text {st }}$ year students, and have lesser apprehensions of the future than the final year students. Overall, $4^{\text {th }}$ year students had the highest positive change in most of the subscales, after the intervention.

At baseline, students belonging to a Nuclear family system had better results in responses for subscales like 'having better respect, actively contributing to happiness and wellbeing of others, and being more engaged in different activities'. This might be due to the fact that they have more opportunities and the freedom to pursue their interests, and also have a greater sense of responsibility for their actions in a nuclear family. Conversely, students in a Joint family fared better in responses for questions like 'living a good purposeful and meaningful life, having more capability, feeling that they were a good person, living a good purposeful life, having better social relationships and being optimistic about future'. This could be due to them having more family support and affection at homes. The spirit of oneness prevailing at homes could provide an environment conducive for such results.

This shows how the experience we gain, the skills we learn, and the wisdom that entails them, is important in determining our outlook towards ourselves and life. Also, across students of all years, the highest increase was recorded for 'being optimistic about the future' subscale, followed by 'being a good person living a good purposeful life' subscale. This can be considered as a very positive and vital effect of the meditation sessions. Having a good hope for the future and living a life that is fulfilling and enriching, is most important in improving our psychological state of mind as well as our overall well-being.

In Heartfulness meditation, when one tunes one's mind to the heart, they live in harmony with themselves and with nature. By regulating our thoughts, a sense of balance is achieved internally, and we can easily govern our emotions and reactions when interacting with others. Heart is a guiding factor that will help us to make choices and decisions, when we learn to listen and be in tune with it. Physical health benefits are also received, because of the relaxation that is produced during meditation, and due to the enhanced sleep quality that we derive as a result.

\section{Conclusion:-}

Psychological flourishing is associated with positive characteristics like being inclined to growth, competency, mastery, and making our lives fulfilling for ourselves, as well as for others. It is a state of being, rather than a feeling or experience.

In many of the previous studies done on psychological flourishing, only less number of participants in the studies was identified to be flourishing. This is an indication of the stress levels experienced in the world we live in. With nursing students, the nature of the profession makes it even more difficult for the students to maintain a good wellbeing. Academic pressures, immature social relationships, peer pressures, tough working environments and middleclass family circumstances affect the psychological aspects of nursing students. Furthermore, they deal with unhealthy patients in their professions, unlike other occupations that involve working with mostly healthy people.

Our study consisted of teachings on various topics of self-development and Heartfulness meditation sessions, to imbibe the concepts and enliven it. Although the students initially had below average psychological flourishing values probably owing to their academic and social pressures, there was a statistically significant improvement in all the students, after the completion of the program. There were, of course, differences in magnitude of these positive responses when analysed in the sub group analysis based on the year of study and family background. Students had a significant difference in their self-confidence and optimism of their future, thereby positively influencing their career. One of the subscales of psychological flourishing explores the attitude of the person in 'actively contributing to the wellbeing of others', which has increased by almost $60 \%$ after the sessions in this study.

Current intervention has been a synergistic combination of teachings on self-development followed by a practical Heartfulness meditation session that facilitated the participants to look within themselves, realize their inner potential, listen to the guidance of their inner self, realize the circumstances and possibilities, and make them more confident to rise up to their expectations. The same is evidenced in the post intervention assessment. This could be 
the possible reason for such a magnitude of psychological flourishing, improved self-confidence, and optimism in the participants.

\section{References:-}

1. Amarnath RG, Prasanthi J, Sharma N, Jenitha S, Rajan C. Efficacy of Heartfulness Meditation in Moderating Vital Parameters-A Comparison Study of Experienced and New meditators. International Journal of Medical Research \& Health Sciences. 2017 Jan 1;6(7):70-8.

2. Black B. Professional Nursing-E-Book: Concepts \& Challenges. Elsevier Health Sciences; 2016 Apr 20.

3. Brotheridge CM, Grandey AA. Emotional labor and burnout: Comparing two perspectives of "people work". Journal of vocational behavior. 2002 Feb 1;60(1):17-39.

4. Diener E, Wirtz D, Biswas-Diener R, Tov W, Kim-Prieto C, Choi DW, Oishi S. New measures of well-being. In Assessing well-being 2009 (pp. 247-266). Springer Netherlands.

5. Diener ED, Emmons RA, Larsen RJ, Griffin S. The satisfaction with life scale. Journal of personality assessment. 1985 Feb 1;49(1):71-5.

6. Fox ML, Dwyer DJ, Ganster DC. Effects of stressful job demands and control on physiological and attitudinal outcomes in a hospital setting. Academy of Management journal. 1993 Apr 1;36(2):289-318.

7. Fredrickson BL, Losada MF. Positive affect and the complex dynamics of human flourishing. American psychologist. 2005 Oct;60(7):678.

8. Fredrickson BL. The role of positive emotions in positive psychology: The broaden-and-build theory of positive emotions. American psychologist. 2001 Mar;56(3):218.

9. Kahneman D, Krueger AB. Developments in the measurement of subjective well-being. Journal of Economic perspectives. 2006 Mar;20(1):3-24.

10. Keyes CL, Shmotkin D, Ryff CD. Optimizing well-being: The empirical encounter of two traditions. Journal of personality and social psychology. 2002 Jun;82(6):1007.

11. Lyubomirsky S, Sheldon KM, Schkade D. Pursuing happiness: The architecture of sustainable change. Review of general psychology. 2005 Jun;9(2):111.

12. McHugh MD, Kutney-Lee A, Cimiotti JP, Sloane DM, Aiken LH. Nurses' widespread job dissatisfaction, burnout, and frustration with health benefits signal problems for patient care. Health Affairs. 2011 Feb 1;30(2):202-10.

13. Mishra S, Sailesh KS, Bashetti S, Archana R, Reddy UK, Jayasree DK, Mukkadan JK. Effect of heartfulness meditation on perceived stress and cognition in hypertensive patients. International Journal of Research in Pharmaceutical Sciences. 2017 Dec 31;8(4):690-2.

14. Ryff CD, Love GD, Urry HL, Muller D, Rosenkranz MA, Friedman EM, Davidson RJ, Singer B. Psychological well-being and ill-being: do they have distinct or mirrored biological correlates?. Psychotherapy and psychosomatics. 2006;75(2):85-95.

15. Sheldon KM, Lyubomirsky S. Achieving sustainable gains in happiness: Change your actions, not your circumstances. Journal of Happiness Studies. 2006 Mar 1;7(1):55-86.

16. Vallerand RJ. The role of passion in sustainable psychological well-being. Psychology of well-Being: Theory, research and practice. 2012 Dec 1;2(1):1. 